\title{
11
}

Ewelina Niedzielska

Uniwersytet Łódzki

http://dx.doi.org/10.18778/8088-905-7.12

\section{O tym, dlaczego ekonomiści potrzebują humanistów}

\section{Wstęp}

Od kilku lat Departament Obrony Stanów Zjednoczonych (Pentagon) prowadzi badania nad potrzebą snu oraz strachem. Celem tych badań jest "stworzenie" idealnego żołnierza pozbawionego potrzeby sennej regeneracji oraz zniwelowanie uczucia prowadzącego do uruchamiania się instynktu samozachowawczego. Żołnierze "szwadronów śmierci” w założeniu mają być zdolni do ciągłej, wytężonej i nastawionej na cel pracy, bez wpływu zatrważającego kontekstu sytuacji, w jakiej się znajdują oraz własnych ułomności (Crary 2015: 9-11). Patrząc jednak szerzej, można pokusić się o stwierdzenie, że działania naukowców z Pentagonu są próbą osadzenia człowieka w emocjonalnej i kontekstowej próżni, pozbawienia go nieefektywnych wewnętrznych i zewnętrznych stymulatorów. Paradoksalnie jednak próba odebrania żołnierzom ludzkich cech przydaje ich człowieczeństwu wagi, bowiem w ten sposób pośrednio zostaje powiedziane: nie jesteśmy w stanie skonstruować takiego szkolenia, treningu ani takiej broni, która wyeliminowałaby z żołnie- 
rzy ludzki pierwiastek. Dlatego musimy skoncentrować się na nich samych.

Przynajmniej w potocznym rozumieniu, nauki ekonomiczne mają za sobą długą historię idealizacji, pozbawiania ludzkich przymiotów, słowem - powolnego osadzania człowieka w swoistej próżni. Na przestrzeni stuleci wpływowi myśliciele, od Pascala, przez Adama Smitha, do Oskara Morgensterna, Johna von Neumanna i Kennetha Arrowa, ukształtowali wizję homo oeconomicusa - człowieka racjonalnego, kierowanego zasadą maksymalizacji użyteczności, funkcjonującego w doskonale konkurencyjnym, dążącym do równowagi świecie. Coraz głośniej mówi się o wątpliwościach związanych z przywołanymi założeniami, które zdominowały ekonomię XIX i XX w. (Klimczak 2015: 70), a ich pokłosie wyraźnie jest widoczne w wykładanych na uczelniach wyższych przedmiotach ekonomicznych oraz finansowych. Ekonomia głównego nurtu wykorzystywała postulat racjonalności do analizy sytuacji, w której człowiek dokonujący wyboru dysponował precyzyjnie określonym celem, pełną informacją oraz kompletną wiedzą co do natury stawianego przed nim problemu (Klimczak 2015: 70). W konsekwencji postulat ten osiągnął wręcz wymiar „hiperracjonalności”, cechującej całą rzeczywistość człowieka (Klimczak 2015: 70). Można powiedzieć, że współczesna ekonomia to wciąż bardziej ekonomika, będąca "nauką o racjonalnej działalności w gospodarce”, w której owa racjonalność zyskała charakter ontologiczny (Musiał 2014: 21).

W niniejszym artykule ekonomia będzie rozumiana na dwa sposoby: jako ewoluujący dyskurs naukowy i forma działalności człowieka, polegającej na wytwarzaniu, dystrybucji oraz konsumpcji dóbr materialnych i niematerialnych, zaś finanse - jako dziedzina wyposażona $\mathrm{w}$ różnego rodzaju techniki, metody, narzędzia, subdyscyplina koncentrująca się na procesach decyzyjnych, związanych z gromadzeniem, wydatkowaniem i przepływem zasobów pieniężnych przez różne podmioty (Sierpińska, 2015: 9). Humanistykę natomiast definiuję jako szeroko rozumiany opis działalności człowieka, funkcjonującego w złożonym systemie społeczno-kulturowym (Iwasiów 2015: 96), którym posłu- 
gują się takie dziedziny jak: etnologia, filozofia, historia, historia sztuki i nauki o sztuce, językoznawstwo oraz kulturoznawstwo (Rozporządzenie 2011). Czy tak określona humanistyka może wnieść istotny wkład do wiedzy ekonomicznej i finansowej oraz czy ewentualna ich wspólna droga powinna zostać wyznaczona przez wzajemne uzupełnianie się, czy też tworzenie wspólnych teorii o charakterze pomostowym? (Bobryk 2014)

\section{Czym jest wartość?}

Z pozoru wydaje się, że różnice między naukami humanistycznymi a ekonomicznymi mieszczą się $\mathrm{w}$ ich właściwościach konstytutywnych: języku, przedmiocie i celu badań oraz reprezentowanych „rzeczywistościach". Można powiedzieć, że lapidarny, wręcz abstrakcyjny język cyfr i tabel wydaje się nie przystawać do humanistycznych, niekiedy bujnych, opisów otaczającego nas świata. Co więcej, reprezentowane przez omawiane nauki fragmenty rzeczywistości zdają się współistnieć jedynie na zasadzie oksymoronu, wszak „literatura rzekomo reprezentuje czyste wartości ducha, ekonomia - również rzekomo - nieczyste zyski" (Czapliński 2013: 8).

Jeśli poddamy refleksji przedmiot badań obu nauk, możemy jednak dostrzec, że stworzenie pewnej wspólnoty komunikacyjnej staje się właściwie nieodzowne. Z oczywistych względów, w tym kontekście przychodzą na myśl sztuka i zbudowany dokoła niej przemysł, pozwalający na przepływ miliardów euro. Zależność między kulturą $\mathrm{w}$ rozumieniu humanistycznym a ekonomią oraz finansami jest w tym kontekście dość wyraźna (zob. The Global Art Market, 2014). Dzieła sztuki, z jednej strony, stwarzają inwestorom możliwość dywersyfikacji portfela, z drugiej zaś - ponieważ ze względu na swoją wartość są mniej wrażliwe na wahania rynków - mogą stanowić formę zabezpieczenia materialnego. W sztukę właściwie wpisany jest więc aspekt związany z wydatkowaniem i przepływem zasobów pieniężnych (Goleń 2013: b.s.). [Istotny w tym kontekście jest jednak 
nie tylko aspekt inwestycyjny, ważny dla finansów, lecz także fundamentalny dla nich problem „wartości”. W związku z rozwojem rynku sztuki powstaje bowiem szereg pytań dotyczących szacowania wartości symbolicznych na ogólnodostępnym rynku produktów bankowych i nadawania wytworom kultury wartości finansowych. W skali światowej można już mówić o powstającej branży Art \& Finance (Rynek sztuki 2013: 5), łączącej sztukę z finansami, obejmującej świadczone przez banki usługi doradcze, zabezpieczenia kredytowe w postaci dzieł sztuki oraz usługi wspierające inwestowanie w rynek sztuki (Rynek sztuki 2013: 20).

Rzecz jasna, można by na tym fragmencie rzeczywistości poprzestać - oddając pole badawcze jednej z nauk lub pozwalając na angażowanie się obydwu - i czerpać przyjemność z fascynującej dyskusji naukowej przedstawicieli dwóch dziedzin. Współczesność zarysowuje jednak inną tendencję. Jeszcze w latach 90. XX w. znany ekonomista, Paul Samuelson twierdził, że cel istnienia przedsiębiorstwa polega na przekształcaniu czynników produkcji w jednolite i trwałe dobro, które będzie odpowiadać na oczekiwania konsumentów (1995: 187). Jeśli ktoś po dziś dzień twierdzi, że przedsiębiorstwa kreują lub chcą kreować trwałe dobra, będące wynikiem czynników produkcji, może się spotkać z niezrozumieniem. Rosnący udział dóbr symbolicznych w konsumpcji wpływa bowiem na relatywną dematerializację ekonomii (Krzysztofek 2012: 16). Wartość produktów wyznaczana jest nie tylko przez ich element materialny, lecz także (niekiedy wręcz przede wszystkim) przez element niematerialny. Odwołanie się w tym kontekście jedynie do rynku sztuki byłoby przesadnym zawężeniem tematu. Szeroko pojęta kultura (historia, tradycje, mitologia itd.) traktowana jest obecnie jako zasób, z którego mogą czerpać korzyści takie dziedziny, jak: turystyka, rynek muzyczny i audiowizualny, architektura oraz wiele innych (Krzysztofek 2012: 17). W tak określonej rzeczywistości zmuszeni są funkcjonować badacze zajmujący się finansami przedsiębiorstw, gospodarstw domowych i finansami publicznymi oraz szeroko pojętą ekonomią.

Już w tym miejscu można zarysować konieczność współpracy przedstawicieli omawianych nauk. Waga tej problematyki jest 
wyznaczana w dwojaki sposób. Z jednej strony chodzi oczywiście o ciągle ewoluujący świat ludzkich wytworów, w którym estetyzacja i dematerializacja przestrzeni i produktów stały się dominujące, a w którym zarówno ekonomiści, finansiści, jak i humaniści muszą się odnaleźć. Z drugiej - zazębianie się tych nauk w ramach pojęcia wartości, będącego dla ekonomii ideą o charakterze metafizycznym, na której opiera się znakomita część jej aparatu pojęciowego (por. Krzysztofek 2012: 16-17) prowokuje do postawienia otwartego pytania o możliwość redefinicji jednego z fundamentów ekonomii oraz o to, w jakim stopniu przedstawiciele nauk humanistycznych mogliby ten proces wesprzeć.

\section{Czy człowiek jest istotą nieracjonalną?}

Przedstawionej refleksji można zarzucić pominięcie problemu celu badawczego obu nauk. Jeszcze do niedawna w ekonomii i finansach dominował paradygmat normatywny, z którego wynikał ich aplikacyjny i predykcyjny charakter. Istotą badań była odpowiedź na pytanie o to, jak powinien postępować człowiek, aby osiagnać zamierzone rezultaty finansowe, co w oczywisty sposób kłóciło się z deskryptywnym charakterem nauk humanistycznych. Warto przy tej okazji zaznaczyć, że zarówno humaniści, jak i ekonomiści koncentrują swoją uwagę na wytworach ludzkiej kultury (Klimczak 2015: 66). Główny nurt ekonomii stosuje jednak do analizy tych wytworów modele idealizacyjne (homo oeconomicus, doskonale konkurencyjny rynek, efektywność rynku kapitałowego), co w założeniu ma pomóc w zrozumieniu złożoności systemu gospodarczego oraz decyzji ekonomicznych (Klimczak 2015: 72).

Jeśli za podstawę analizy przyjmiemy, jak do niedawna, konstrukt homo oeconomicus, to główny aspekt badań ekonomicznych skierowany zostanie na problem racjonalności. Oznacza to założenie, że człowiek ma określone preferencje, posiada zdolność identyfikacji swoich potrzeb, ich hierarchizacji oraz zaspokajania ich w taki sposób, aby maksymalizować satysfak- 
cję (Czerwonka, Gorlewski 2012: 22). W praktyce oznacza to, ze inwestor podejmując decyzje działa w sposób, który zapewni mu maksymalizację korzyści, a otrzymywane informacje zawsze interpretuje właściwie. Ponadto, sama informacja na rynku racjonalnych inwestorów odbierana jest przez nich wszystkich jednakowo, co oznacza, że istnieją obiektywnie dobre i złe informacje, które odpowiednio interpretowane są w sposób pozytywny i negatywny (Czerwonka, Gorlewski 2012: 25). Normatywne podejście do analizy zachowań człowieka zaowocowało więc aksjomatyzacją jego zachowań, co umożliwiało budowanie modeli ekonomicznych, w szczególności w nurcie neoklasycznym (Giza 2014: 46). Ekonomii należy się jednak odczarowanie jej bezdusznego obrazu. W latach 70. XX w. normatywny porządek finansów i ekonomii został bowiem poważnie naruszony, co ukazało konieczność włączenia do analiz opisu, pozbawionego wartości aplikacyjnej.

Nieco ponad 10 lat po tym, jak w latach 40. XX w. von Neumann i Morgenstern stworzyli teorię oczekiwanej użyteczności, opartą na szeregu aksjomatów, Herbert Simon zaproponował teorię użyteczności ograniczonej (nazywanej również teorią ograniczonej racjonalności). Stwierdził, że osiągnięcie pełnej racjonalności nie jest możliwe, ponieważ człowiek dysponuje jedynie ograniczonymi zdolnościami przetwarzania informacji. Dodatkowo jego analityczne możliwości hamują takie czynniki, jak: czas, brak informacji o wszystkich alternatywach oraz ich własnościach, a także brak kompetencji do przeprowadzenia wszelkich obliczeń, niezbędnych do podjęciach racjonalnej decyzji. Człowiek, zdaniem Simona, był "skąpcem poznawczym”, a jego proces decyzyjny kończył się w momencie odnalezienia satysfakcjonującej opcji wyboru, a nie opcji najlepszej spośród wszystkich możliwych (Kotlarek 2016: 106-108). W tym samym czasie, kiedy Simon otrzymał Nagrodę Nobla (1978), nad teorią prospektu pracowali Daniel Kahneman i Amos Tversky (1979). Pomijając bogactwo stworzonego przez nich paradygmatu, w niniejszych rozważaniach istotne są ich dwa spostrzeżenia. Po pierwsze, człowiek nie jest racjonalny, a przynajmniejnie w takim sensie, w jakim zakładali von Neumann i Morgenstern. Po dru- 
gie, na nasze decyzje wpływa kontekst, w jakim je podejmujemy. Na podstawie badań empirycznych Kahneman i Tversky (1979) udowodnili, że jeśli człowiek znajduje się w obszarze możliwych strat, to zachowuje się w taki sposób, aby ich uniknąć, nawet jeśli oznacza to podjęcie większego ryzyka ${ }^{1}$. Innymi słowy, człowiek nie porusza się w próżni, a istotny wpływ na jego działanie ma kontekst sytuacji, w jakiej się znajduje. Teoria prospektu zapoczątkowała w finansach i ekonomii nurt, nazywany ekonomią behawioralną i finansami behawioralnymi, które rzuciły wyzwanie utartym założeniom ekonomii neoklasycznej. Należy zaznaczyć, że analizy wskazanych badaczy, przynajmniej w pewnej części, są zbieżne z założeniami tzw. szkoły austriackiej, której przedstawiciele odrzucili obiektywizm na rzecz subiektywizmu poznawczego (Huerta de Soto 2016: 3) Jeden z przedstawicieli tego nurtu, Friedrich von Hayek, twierdził, że podejmowanie decyzji jest związane z możliwościami ludzkiego umysłu w tym sensie, że został on ukształtowany w procesie kulturowej ewolucji (poprzez interakcje, występujące w kontekście społecznym oraz instytucjonalnym). Z jednej strony umysł stanowi dla człowieka poznawcze ograniczenie, z drugiej - otwiera przed nim możliwości adaptacyjne (Hayek 1952) .

Za sprawą szkoły austriackiej, nowej ekonomii instytucjonalnej, ale przede wszystkim finansów behawioralnych, część ekonomistów podważa znaczenia, nadane człowiekowi i gospodarce przez ekonomię neoklasyczną (por. Klimczak 2015: 76). Czy w związku z tym można stwierdzić, że rezygnują oni z założenia racjonalności natury ludzkiej i ostatecznie rozstają się z jego ontologicznym ciężarem? Udzielenie w tym przypadku odpowiedzi twierdzącej byłoby jednak przekłamaniem rzeczywistości. Wydaje się raczej, że naukowcy pozwolili człowiekowi wyjść z próżni i realizować jego racjonalność w określonym kontekście kulturowym, społecznym i sytuacyjnym, przyznając tym samym, że ma ona charakter ograniczony. To stwierdzenie nie jest, oczywiście, dla nauki żadnym novum. Na przełomie lat

${ }^{1}$ Ekonomia neoklasyczna zakłada, że człowiek co do zasady charakteryzuje się awersją do ryzyka. 
60 i 70. XX w. G. Hofstad przeprowadził badania na pracownikach IBM, na podstawie których zaproponował wskaźnik unikania niepewności (Uncertainty Avoidance Index - UAI) i wykazał, że kraje Ameryki Łacińskiej, Europy, kraje śródziemnomorskie, Korea Północna i Japonia cechuje silne unikanie niepewności, natomiast większość krajów azjatyckich (poza tymi, które zostały wymienione), afrykańskich, anglosaskich i nordyckich cechuje niska skłonność do unikania ryzyka (Hajduga 2013: 49-50; Majewska-Bielecka 2012: 96-98). W podobnym czasie (lata 70. XX w.) Richard Lynn przeprowadził badania na temat poziomu niepokoju społecznego w różnych krajach, z których wynikało, że np. Japończycy oraz Francuzi odczuwają wysoki niepokój społeczny, w przeciwieństwie do Irlandczyków i Anglików (Majewska-Bielecka 2012: 98). W 2005 r. badania nad występowaniem awersji do ryzyka $\mathrm{w}$ różnych kulturach przeprowadzili J. X. Fan i J. J. Xiao, wykazując istnienie w tym zakresie znaczących różnic między przedstawicielami regionów kulturowych. Mieszkańcy krajów azjatyckich wykazywali się większą tolerancją wobec ryzyka finansowego oraz mniejszą awersją do strat niż mieszkańcy Stanów Zjednoczonych oraz krajów europejskich (zob. Fan, Xiao 2005). Takie różnice tłumaczyć może zaproponowana przez E. U. Weber i C. K. Hsee hipoteza, mówiąca o tym, że kraje kolektywistyczne (czyli np. większość krajów azjatyckich) cechuje usankcjonowany kulturowo "parasol ochronny" w postaci wsparcia rodziny i przyjaciół w sytuacji doświadczania problemów finansowych (Majewska-Bielecka 2012: 100). Z badań T. Hens, M. O. Rieger wynika, że przedstawiciele krajów o nastawieniu indywidualistycznym wykazują się wyższym poziomem awersji do straty, co wynikać może z tego, że realne wsparcie w trudnościach finansowych nie jest tam tak oczywiste (Majewska-Bielecka 2012: 100).

Okazuje się więc, że jedno z najważniejszych pojęć ekonomii i finansów, jakim jest ryzyko, ma nie tylko wyraźny aspekt kulturowy, ale właściwie definiowane jest przez kulturę. Oznacza to, że aby zrozumieć, co oznacza niepewność, musimy zrozumieć, co oznacza sytuacja znana, a do tego kontekst kulturowy wydaje się niezbędny. O ile problem ten rozmywa się w przypadku 
globalnych rynków kapitałowych, o tyle wydaje się bardzo wyraźny w przypadku zarządzania przedsiębiorstwami, zarówno w skali lokalnej, jak i międzynarodowej.

\section{Zakończenie}

Zależności między humanistyką a ekonomią i finansami (przez co rozumiem nie tylko zainteresowanie humanistycznym przedmiotem badań, lecz także konieczność zaangażowania humanistów do współuczestniczenia w procesie badawczym i wyjaśnianiu zjawisk ekonomicznych i finansowych) przejawiają się na trzy sposoby. Po pierwsze, wielu przedstawicieli ekonomii zwraca coraz większą uwagę na człowieka sensu stricto, a nie na służący uproszczeniom konstrukt. W tym sensie ekonomia i finanse zbliżają się do nauk humanistycznych. Po drugie, coraz ważniejszą rolę $\mathrm{w}$ refleksji ekonomicznej i finansowej odgrywa kontekst sytuacyjny i społeczno-kulturowy. Nauki humanistyczne, choć pozbawione praktycznego znaczenia, mogą okazać się pomocne w udzielaniu odpowiedzi na pytania, , jak" oraz „dlaczego", dostarczając wiedzy o rzeczywistości, która jest efektem ludzkiego działania i w której człowiek zmuszony jest się poruszać (Górski 2016: 6, co, w kontekście czysto finansowym i ekonomicznym, ma niebagatelny wpływ na jego proces decyzyjny. Po trzecie, widoczne w rzeczywistości zazębianie się pól badawczych wymaga od humanistów i finansistów stworzenia wspólnej płaszczyzny komunikacyjnej. Humanistyki - dzięki jej deskryptywnemu charakterowi - nie można już chyba pojmować jedynie jako nauki chroniącej dziedzictwo kulturowe, dbającej o depozyt tradycji. Jest ona również „źródłem samowiedzy, poznania samego człowieka" (Sarnowska-Temeriusz 2009: 68).

Choć doświadczenie pokazuje, że wynalazki wojska prędzej czy później przedostają się do cywilnej rzeczywistości i, być może, kiedyś zostaniemy pozbawieni snu, funkcjonując $\mathrm{w}$ wielogodzinnych "trybach czuwania" (Crary 2015: 9-11), to wydaje się, że rzeczywistość nauki ekonomicznej, przynajmniej w pewnym stopniu, obrała odwrotny, bardziej humanistyczny kierunek. 


\section{Literatura}

Bobryk J. (2014), Transhumanizm. Cognitive science i wyzwania dla nauk społecznych, "Studia Socjologiczne", nr 3 (214).

Crary J. (2015), 24/7. Późny kapitalizm i koniec snu, tłum. D. Żukowski, Wydawnictwo Karakter, Kraków.

Czerwonka M., Gorlewski B. (2012), Finanse behawioralne. Zachowania inwestorów i rynku, Oficyna Wydawnicza SGH, Warszawa.

Fan J. X., Xiao J. (2005), A Cross-Cultural Study in Risk Tolerance: Comparing Chinese and Americans, http://papers.ssrn.com/sol3/papers.cfm?abstract_ id=939438 [dostęp: 27.06.2016].

Giza W. (2014), Normatywny wymiar koncepcji homo oeconomicus, „Studia Ekonomiczne. Zeszyty Naukowe Uniwersytetu Ekonomicznego w Katowicach", nr 180, cz. 1.

The Global Art Market, with a focus on the US and China (2014), ed. C. Mc Andrew, The European Fine Art Foundation, New York, https://www.creatrust.com/ medias/fichiers/tefaf_art_market_report_2014.pdf [dostęp: 27.06.2016].

Goleń G. (2013), Inwestowanie w sztukę. Prawdy i mity, https://mocak.pl/inwestowanie-w-sztuke-prawdy-i-mity-grzegorz-golen [dostęp: 27.06.2016].

Górski P. (2016), Zarządzanie i nauki o zarzadzaniu w perspektywie humanistycznej, http://www.academia.edu/5162833/Zarz\%C4\%85dzanie_i_nauki_o_zarz\%C4\%85dzaniu_w_perspektywie_humanistycznej [dostęp: 27.06.2016].

Hajduga E. (2013), Wartości kulturowe w rachunkowości wedtug koncepcji Graya $i$ Hofstede'a, „Finanse, Rynki Finansowe, Ubezpieczenia”, nr 58.

Huerta de Soto J. (2016), Spór metodologiczny (Methodenstreit) szkoły austriackiej, tlum. J. Lewiński, M. Zieliński, http://mises.pl/pliki/upload/methodenstreit.pdf [dostęp: 27.06.2016].

Iwasiów S. (2015), Humanistyka i ekonomia na początku XXI wieku. Rozważania wokół ksiązki Jamesa F. Englisha "Ekonomia prestiżu. Nagrody, wyróżnienia $i$ wymiana wartości kulturowej" oraz innych rozpraw humanistyczno-ekonomicznych, „Edukacja Ekonomistów i Menedżerów”, nr 2 (36).

Jachna T., Sierpińska M. (2015), Metody podejmowania decyzji finansowych, Wydawnictwo Naukowe PWN, Warszawa.

Kahneman D., Tversky A. (1979), Prospect Theory: An Analysis of Decision under Risk, "Econometrica", Vol. 47, No. 2.

Klimczak B. (2015), Ludzie i ekoni. Psychologizm i racjonalizm w ekonomii, [w:] Nauki ekonomiczne. Stylizowane fakty a wyzwania wspótczesności, red. B. Fiedor, Polskie Towarzystwo Ekonomiczne, Warszawa.

Kotlarek P. (2016), Racjonalność w ujęciu ekonomii behawioralnej, http://www.ue. katowice.pl/fileadmin/_ migrated/content_uploads/10_P.Kotlarek_Racjonalnosc_w_ujeciu_ekonomii....pdf [dostęp: 27.06.2016].

Krzysztofek K. (2012), Zmiana permanentna? Refleksje o zmianie społecznej w epoce technologii cyfrowych, "Studia Socjologiczne”, nr 4 (207). 
Majewska-Bielecka D. (2012), Wielokulturowy aspekt skłonności do ryzyka, „Zeszyty Naukowe ZPSB Firma i Rynek", nr 1.

Musiał G. (2014), Ontologia ekonomii, „Zeszyty Naukowe Wyższej Szkoły Bankowej w Poznaniu", t. 54, nr 3.

Rozporządzenie MNiSzW z 8 sierpnia 2011 r. w sprawie obszarów wiedzy, dziedzin nauki i sztuki oraz dyscyplin naukowych $i$ artystycznych, Dz. U. z dnia 30 sierpnia $2011 \mathrm{r}$.

Rynek sztuki (2013), http://rynekisztuka.pl/wpcontent/uploads/2013/04/pl_artbanking_pl.pdf [dostęp: 27.06.2016].

Samuelson P., Nordhaus W. D. (1995), Ekonomia, PWN, Warszawa.

Sarnowska-Temeriusz E. (2009), Panel Humanistyka dla przyszłości. Potencjał - szanse-perspektywy, "Nauka”, nr 1. 